\title{
Setting Better-Informed Climate Targets for New Zealand: The Influence of Value and Modeling Choices
}

Chandrakumar, Chanjief; Malik, Arunima; McLaren, Sarah J; Owsianiak, Mikoaj; Ramilan, Thiagarajah; Jayamaha, Nihal P; Lenzen, Manfred

\section{Published in:}

Environmental Science and Technology

Link to article, DOI:

10.1021/acs.est.9b06991

Publication date:

2020

Document Version

Peer reviewed version

Link back to DTU Orbit

Citation (APA):

Chandrakumar, C., Malik, A., McLaren, S. J., Owsianiak, M., Ramilan, T., Jayamaha, N. P., \& Lenzen, M. (2020). Setting Better-Informed Climate Targets for New Zealand: The Influence of Value and Modeling Choices. Environmental Science and Technology, 54(7), 4515-4527. https://doi.org/10.1021/acs.est.9b06991

\section{General rights}

Copyright and moral rights for the publications made accessible in the public portal are retained by the authors and/or other copyright owners and it is a condition of accessing publications that users recognise and abide by the legal requirements associated with these rights.

- Users may download and print one copy of any publication from the public portal for the purpose of private study or research.

- You may not further distribute the material or use it for any profit-making activity or commercial gain

- You may freely distribute the URL identifying the publication in the public portal 
1 Chandrakumar, C.; Malik, A.; McLaren, S. J.; Owsianiak, M.; Ramilan, T.; Jayamaha, N. P.; Lenzen, M.

2 Setting Better-Informed Climate Targets for New Zealand: The Influence of Value and Modeling 3 Choices. Environ. Sci. Technol. 2020, 54 (7), 4515-4527. https://doi.org/10.1021/acs.est.9b06991. 


\section{Setting Better-Informed Climate Targets for New Zealand: 5 The Influence of Value and Modeling Choices}

6 Chanjief Chandrakumar ${ }^{a, b, *}$, Arunima Malik ${ }^{c, d}$, Sarah J McLaren ${ }^{a, b}$,

7 Mikołaj Owsianiak ${ }^{\mathrm{e}}$, Thiagarajah Ramilan ${ }^{\mathrm{b}, \mathrm{f}}$, Nihal P Jayamaha ${ }^{\mathrm{g}}$, Manfred Lenzen ${ }^{\mathrm{c}}$

8 aNew Zealand Life Cycle Management Centre, c/o Massey University, Palmerston North 4442,

$9 \quad$ New Zealand

10 bSchool of Agriculture and Environment, Massey University, Palmerston North 4442, New 11 Zealand

12 ISA, School of Physics, The University of Sydney, Sydney, New South Wales 2006, Australia

13 dSydney Business School, The University of Sydney, Sydney, New South Wales 2006, Australia

14 eDivision for Quantitative Sustainability Assessment, Department of Management

15 Engineering, Technical University of Denmark, Produktionstorvet 424, 2800 Kgs. Lyngby,

16 Denmark

17 SChool of Food and Advanced Technology, Massey University, Palmerston North 4442, New 18 Zealand

19 SSchool of Agriculture and Food, The University of Melbourne, Melbourne, Victoria 3010, 20 Australia

$21 \quad *$ C.Chandrakumar@massey.ac.nz 
Quantifying greenhouse gas (GHG) emissions and setting emissions budgets for anthropogenic systems are influenced by several value and modeling choices. This study, for the first time, quantified the influence of choice of GHG accounting approach, GHG metric, time horizon, climate threshold, global emissions budget calculation method, and effortsharing approach, taking New Zealand (NZ) as a case study. First, NZ's production- and consumption-based emissions were quantified using multi-regional input-output analysis and applying different GHG metrics (global warming and temperature potentials) and time horizons (20 and 100 years). Second, global emissions budgets for $1.5^{\circ} \mathrm{C}, 2{ }^{\circ} \mathrm{C}$, and $1 \mathrm{Wm}^{-2}$ climate thresholds were estimated. Budget shares were then assigned to NZ using two effortagainst the assigned shares. Finally, the analysis was undertaken at the NZ sector level. The results showed that, for each GHG accounting approach, NZ's total emissions exceeded their budget shares, irrespective of the choices; the largest source of uncertainty was the choice of global emissions budget calculation method, followed by GHG metric, climate threshold, analysis showed that, while most sectors exceeded their budget shares, some performed within them. The ranking of uncertainty sources was quite different at the sector level, with the choice of effort-sharing approach providing the largest source of uncertainty. Overall, the study indicates the importance of handling value and modeling choices in a transparent way when quantifying emissions and setting emissions budgets for anthropogenic systems. 
43 Keywords: science-based targets, absolute sustainability, value choice, modeling choice,

44 carbon budget, climate change, multi-regional input-output analysis, life cycle assessment,

$45 \quad$ New Zealand 


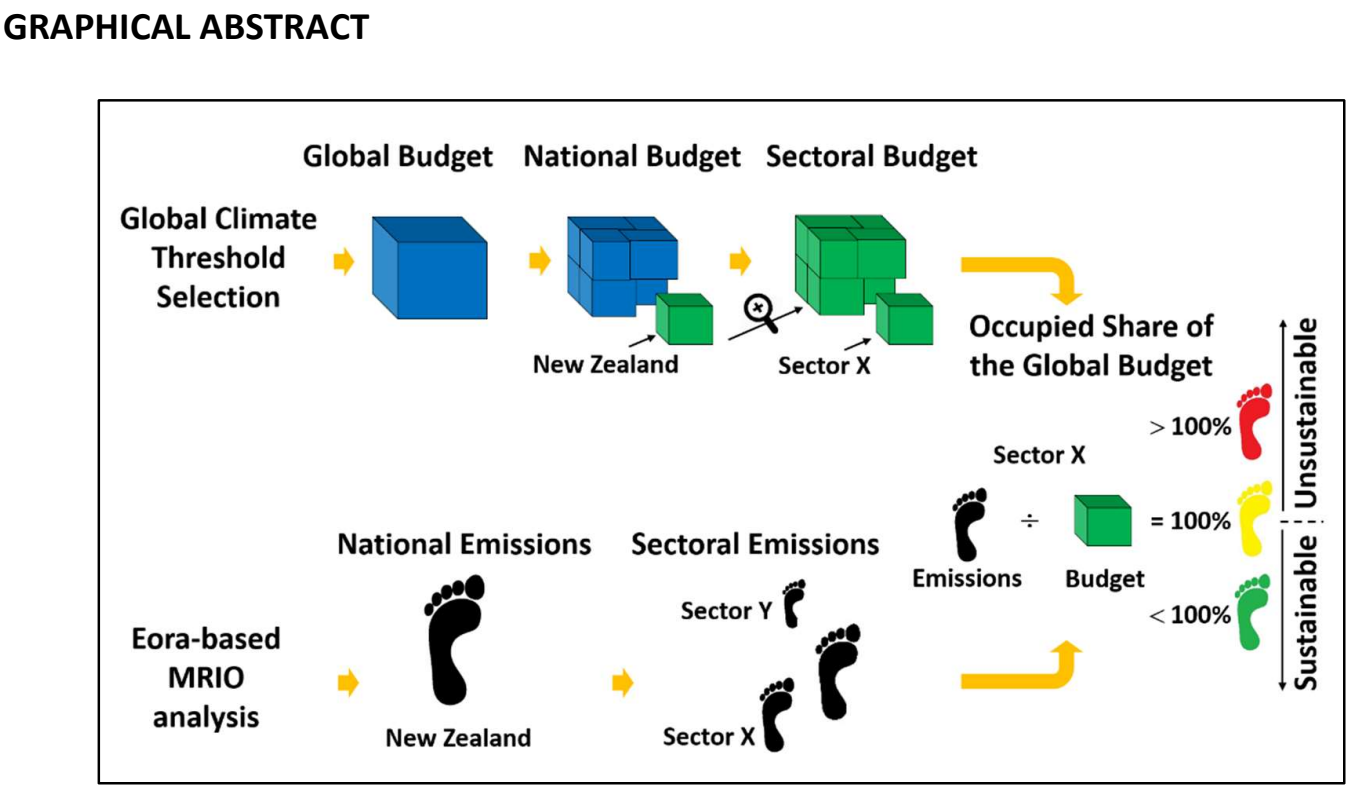




\section{INTRODUCTION}

48 Anthropogenic greenhouse gas (GHG) emissions increase the risk of transgressing global

49 climate thresholds. ${ }^{1,2}$ Existing climate change indicators based on different GHG emissions 50 metrics such as global warming potential ${ }^{3}$ and global temperature change potential ${ }^{4}$ provide $^{2}$

51 information about the climate change performance of an anthropogenic system (which can

52 be either a product/process, service, company, sector, country or the entire Earth). However,

53 they do not provide information about that system's performance relative to global climate

54 thresholds. ${ }^{5}$ Therefore, they can be regarded as providing insufficient information to mitigate

55 climate change globally.

56 Acknowledging the existence of global climate thresholds, researchers have started 57 developing so-called absolute environmental sustainability assessment (AESA) methods. ${ }^{6-9}$ An 58 AESA method, in general, quantifies the GHG emissions of an anthropogenic system using 59 climate change indicators (based on GHG metrics) and provides information on that system's 60 climate change performance relative to a chosen climate threshold. ${ }^{10,11}$ Several value and 61 modeling choices are made during this modeling process, which are potentially important 62 sources of uncertainty. These choices include selection of:

63 (i) A GHG accounting approach to calculate the GHG emissions (aka carbon footprint)

(ii) A GHG metric and time horizon to estimate the aggregated impact of different GHGs associated with the chosen anthropogenic system.

67 (iii) A global climate threshold.

68 (iv) An estimated (GHG) emissions budget for the chosen global climate threshold.

69 (v) An effort-sharing approach for assigning a share of the global emissions budget to the chosen anthropogenic system. 
production-based (also referred to as territorial in some studies) or consumption-based. ${ }^{12-14}$

73 Production-based accounting approaches, in general, account for the GHG emissions released

by the producer within a specific territory; hence, these approaches generally do not consider

the emissions associated with imported goods and services used by the producer. ${ }^{15}$ On the other hand, consumption-based accounting approaches allocate all emissions of the production of goods and services to the final consumer; these methods do not account for the emissions associated with additional goods and services that are exported. ${ }^{12,13}$ Each of these approaches provides different insights to support climate change mitigation activities and policymaking; hence, in general, both approaches are used in a complementary way. ${ }^{16-18}$

Once the GHG accounting approach is chosen, the emissions of all GHGs (such as carbon dioxide, methane, nitrous oxide, chlorofluorocarbons, and hydrofluorocarbons) associated with the chosen system are quantified using methods such as carbon footprinting ${ }^{19}$ and environmentally-extended input-output analysis. ${ }^{20,21}$ The measured GHGs are then and a time horizon which assign a weighting (referred to as a characterisation factor in Life

Cycle Assessment) to the emission of each individual GHG. Global warming potential (GWP) and global temperature potential (GTP) are the commonly used metrics, ${ }^{22,} 23$ the former represents the heat absorbed over a given time horizon due to a GHG emission, whereas the latter expresses the change in the atmospheric global mean temperature at the end of the time horizon. ${ }^{24}$ GWP calculated for a 100 -year time horizon (GWP100) is commonly used in carbon footprinting methodologies as well as in the United Nations Framework Convention on Climate Change (UNFCCC) and its Kyoto Protocol, ${ }^{19,25}$ although alternatives such as GWP 20 and GTPs at 100, 50, and 20 years (GTP100, GTP 50, and GTP 20 respectively) exist. 4, 26, 27 
Once the GHG emissions are assessed, the aggregated result is benchmarked against an assigned share of the global emissions budget, which requires choosing an appropriate global climate threshold (hereafter, climate threshold). There are several climate thresholds proposed in the literature. ${ }^{25,28,29}$ For example, the international policies of the UNFCCC were centred on limiting the global mean temperature increase to 2 degree Celsius $\left({ }^{\circ} \mathrm{C}\right)$ above preindustrial levels. ${ }^{30}$ This long-term goal was lately revised under the Paris Agreement to holding the increase well below $2{ }^{\circ} \mathrm{C}$ and pursuing efforts to limit it to $1.5^{\circ} \mathrm{C} .{ }^{28,31}$ At the same time, the planetary boundaries framework has defined more ambitious (two) climate thresholds that should not be transgressed: a global average atmospheric $\mathrm{CO}_{2}$ concentration of 350 parts per million (ppm) $\mathrm{CO}_{2}$ and an increase in radiative forcing of 1 watt per square metre $\left(\mathrm{Wm}^{-2}\right) \cdot{ }^{29}$ However, staying within these climate thresholds seems ambitious as it requires rapid and dramatic changes in how governments, businesses, and societies currently operate.

The chosen climate threshold should then be translated into a measurable global emissions budget; different methods exist for this purpose. ${ }^{32-34}$ For example, Bjørn and Hauschild ${ }^{33}$ proposed a method to estimate a global emissions budget using the GEOCARB model for $\mathrm{CO}_{2}$ and the model of Shine et al. ${ }^{4}$ for other GHGs. Using this method, they estimated the global emissions budgets for the $1 \mathrm{Wm}^{-2}$ and $2{ }^{\circ} \mathrm{C}$ climate thresholds (and using the GWP100 metrics)- 3.6 and 6.8 gigatonnes carbon dioxide equivalent per year $\left(\mathrm{GtCO}_{2}\right.$-eq $\left.\cdot \mathrm{yr}^{-1}\right)$, respectively (see Methods, Supplementary Information (SI) 1 for details). At the same time, Doka $^{32}$ proposed an alternative method to translate the increase in radiative forcing into a global emissions budget using so-called absolute GWPs of different GHGs. By applying this method, Doka ${ }^{32}$ estimated the global emissions budget for the $1 \mathrm{Wm}^{-2}$ climate threshold (10.9 $\mathrm{GtCO}_{2}$-eq $\cdot \mathrm{yr}^{-1}$ for the GWP100 metric) (see Methods). Thus, the budget 
calculated using the method of Doka ${ }^{33}$ (for GWP 100) is three times higher than the budget calculated using the method of Bjørn and Hauschild. ${ }^{33}$ There are additional methods that propose different global emissions budgets for the same climate thresholds ${ }^{34,}{ }^{35}$ (see SI 1 section 1).

Finally, to assign a share of the global emissions budget to a chosen anthropogenic system (e.g., an economic sector of a country), there are a wide range of effort-sharing approaches based on different equity principles such as grandfathering (aka historical responsibility), population, territorial area, economic output (or value addition), and final consumption expenditure. ${ }^{36-39}$ Each effort-sharing approach has its own benefits and limitations. For example, the grandfathering approach effectively rewards the larger emitters with larger emissions budget shares, while leaving smaller emitters with smaller (or even zero) emissions budget shares. ${ }^{36,40}$ And the population-based approach equally shares the global emissions budget between all the individuals in the world; this means that countries with lower populations get smaller shares of the budget even if they have economic activities whose outputs benefit other countries. ${ }^{36,41}$ Given each effort-sharing approach effectively rewards some countries and/or sectors, the choice of effort-sharing approach to assign a share of the global emissions budget is generally considered normative and non-scientific. ${ }^{36,38-40}$

It is therefore evident that value and modeling choices need to be made when quantifying the GHG emissions and defining emissions budgets for anthropogenic systems. To that end, recent studies have started addressing the influence of these value and modeling choices; however, those efforts are limited to one $\mathrm{s}^{36,40-42}$ or two $\mathrm{tw}^{33,38,43,44}$ choices. While the effortsharing approach is the commonly assessed choice, ${ }^{36,38,40,41}$ some studies have focused on other choices such as GHG accounting approach, ${ }^{43-45}$ GHG metric (including time horizon), ${ }^{4,}$ 24, 
14146 and global climate threshold. ${ }^{33,}{ }^{38}$ However, the influence of the choice of method for

142 calculating the global emissions budget has not been assessed yet. More importantly, no

143 study to date has assessed the influence of all these choices together in a single study.

144 This study, therefore, for the first time, assessed the influence of all the above-mentioned 145 value and modeling choices on the overall climate change performance of an anthropogenic 146 system- using a case study of New Zealand. New Zealand is a relatively complex, developed 147 economy which recently passed a Zero Carbon Bill, with the aim of reducing net GHG 148 emissions to zero by $2050 .{ }^{47,} 48$ To make progress towards achieving the aim of the Bill, it is 149 necessary to define an emissions budget (based on a chosen climate threshold) for New 150 Zealand's economic activities, and implement climate action programs with the goal of 151 performing within this emissions budget as soon as possible. Economic sector-level emissions 152 budgets provide a pragmatic basis upon which to develop these climate action programs. In 153 this context, using both production- and consumption-based accounting approaches, the 154 GHG emissions of the New Zealand economy for the reference year 2011 (i.e. the latest year 155 available on the Eora26 multi-regional input-output database ${ }^{49,50}$ at the time of this study) 156 were calculated at a sector level and benchmarked against a range of scenarios developed 157 using the identified value and modeling choices. 


\section{METHODS}

159 This section provides an overview of the assessment methodology. It then describes the 160 procedure for calculating production- and consumption-based GHG emissions, and the 161 selected climate thresholds, global emissions budgets, and methods for assigning shares of

162 the global emissions budget to New Zealand and finally to its economic sectors.

Overall Assessment Methodology

164 The assigned shares of the global emissions budget (SoGEB) for New Zealand and its economic 165 sectors were calculated using eq 1.

$$
\text { SoGEB }{ }_{X, E S A}=G E B \times \mathrm{aS}_{\mathrm{ESA}}
$$

Where SoGEB $\mathrm{X}_{\mathrm{X}, \mathrm{ESA}}$ is the SoGEB assigned to anthropogenic system $\mathrm{X}$ (which can be either New Zealand or its economic sector), using the selected effort-sharing approach (ESA), GEB is the global emissions budget related to a given climate threshold, and $\mathrm{aS}_{\mathrm{ESA}}[\%]$ is the percentage share assigned to $X$, using the chosen ESA. The climate change performance of $X$ is given as an occupied share of the global emissions budget, as represented in eq 2 .

$$
\text { ocCSOGEB }_{X, E S A}=\frac{G H G_{X}}{\text { SOGEBX,ESA }_{X}} \times 100 \%
$$

173 Where occSoGEB ${ }_{X, E S A}$ is the SoGEB occupied by $X$ using the chosen ESA. GHG is the GHG

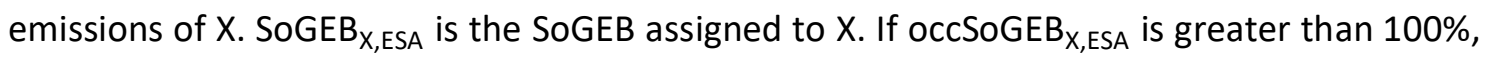
$\mathrm{X}$ can be considered as unsustainable with regards to the chosen global climate threshold.

\section{Calculation of GHG Emissions of New Zealand and Economic Sectors}

To calculate the production- and consumption-based GHG emissions of New Zealand, a global environmentally extended multi-regional input-output (MRIO) analysis was undertaken using a global MRIO database called Eora26. Eora26 provides a time series of input-output and trade tables with matching environmental (including climate change) and 
satellite of Eora 26 accounts for $24 \mathrm{GHGs}$ including $\mathrm{CO}_{2}$, methane $\left(\mathrm{CH}_{4}\right)$, nitrous oxide $\left(\mathrm{N}_{2} \mathrm{O}\right)$,

chlorofluorocarbons, hydrochlorofluorocarbons, hydrofluorocarbons, chlorocarbons, and halons (a full list is available in SI2). For the methodology of the Eora-based MRIO analysis, see Lan et al. ${ }^{51}$ and Malik and Lan. ${ }^{52}$ Given some of the 26 sectors are similar in terms of their activities, they were combined together (after calculating the GHG emissions of each of those 26 sectors) in order to more easily interpret the results, following the approach used in a previous study. ${ }^{17}$ Transport, and transport equipment were combined and named 'transport and equipment'. Likewise, service-providing sectors were aggregated as (i) 'financial and trade-related services'; and (ii) 'other services'. Finally, the 'others' and 'private households' sectors were aggregated and named 'miscellaneous'. A detailed description is available in SI2.

\section{Selection of GHG Metrics and Time Horizons}

To weight and aggregate the GHGs of each sector (both production- and consumptionbased), three alternative GHG metrics were used: GWP100, GWP20, and GTP 100. As discussed in the Introduction, GWP represents the heat absorbed over a given time horizon due to a GHG emission (i.e. change in radiative forcing) and GTP expresses the change in the atmospheric global mean temperature at the end of the time horizon due to the emission. ${ }^{24}$

25 The different time horizons were chosen in order to capture the differences in climate change impacts of long- and short-lived GHGs; for example, the GWP100 and GWP 20 weightings of $\mathrm{CH}_{4}$ are 28 and 84 respectively. ${ }^{25}$

\section{Selection of Global Climate Thresholds and Global Emissions budgets} target; ${ }^{30}$ and the $1 \mathrm{Wm}^{-2}$ radiative forcing threshold in the planetary boundaries. ${ }^{29}$ 
To translate the chosen climate thresholds into global emissions budgets, the method proposed by Bjørn and Hauschild ${ }^{33}$ was first applied. As described in the Introduction, Bjørn and Hauschild ${ }^{33}$ estimated global emissions budgets for the $1 \mathrm{Wm}^{-2}$ and $2{ }^{\circ} \mathrm{C}$ climate thresholds and using the GWP100 metric. For this analysis, the $1.5^{\circ} \mathrm{C}$ global emissions budget 209 (for GWP100) was obtained by taking the sustained emissions of each GHG that lead to a steady state temperature increase of $2{ }^{\circ} \mathrm{C}$, scaling them down to represent a steady state temperature increase of $1.5^{\circ} \mathrm{C}$, and then multiplying those emissions with their respective GWP100 weightings. This resulted a $1.5{ }^{\circ} \mathrm{C}$ global emissions budget (for GWP100) of 5.1 $\mathrm{GtCO}_{2}$-eq $\cdot \mathrm{yr}^{-1}$. Subsequently, the global emissions budgets for all three climate thresholds, using alternative GHG metrics (GWP20 and GTP100), were estimated (SI1 sections 2-10).

The same budgets were then quantified using Doka's method. ${ }^{32}$ As described in the Introduction, Doka ${ }^{32}$ estimated the $1 \mathrm{Wm}^{-2}$ global emissions budget by translating the increase in radiative forcing using absolute GWPs of different GHGs. Following Doka's metho $^{32}$ and using relevant radiative forcing values, ${ }^{31,53}$ the global emissions budgets (using absolute GWP100) for the 1.5 and $2{ }^{\circ} \mathrm{C}$ climate thresholds were estimated as 20.7 and 28.4 $\mathrm{GtCO}_{2}$-eq $\cdot \mathrm{yr}^{-1}$ respectively. Likewise, the global emissions budgets for all three climate thresholds, applying alternative GHG metrics, can be quantified (see SI1 section 11).

\section{Assigning a Share of the Global Emissions budget}

In this study, two commonly used effort-sharing approaches were chosen to assign a

224 share of the global emissions budget (SoGEB) to different New Zealand sectors. One of them was the grandfathering approach which assigns a SoGEB to a sector based on its relative contribution to the global GHG emissions that occurred in a chosen reference year. ${ }^{36,41}$ The other one was the economic value approach which assigns a SoGEB to a sector using economic indicators such as gross value added (GVA) and final consumption expenditure (FCE). The GVA 
method is applied in studies based on a production-based accounting approach in which a

230 SoGEB is assigned to a sector based on its relative contribution to the gross value-added

231 globally. ${ }^{44,54}$ The FCE method is applied in studies that use a consumption-based accounting

232 appraoch; a SoGEB is assigned to a system based on its relative share of the global final

233 consumption expenditure. ${ }^{38,44}$ While the former (i.e. GVA) associates responsibility for GHG

234 emissions from production activities with the economic benefits (e.g., employment, earning

235 foreign exchange, and tax revenues) obtained by different supply chain actors, the latter (FCE)

236 represents consumer preferences for different products and services that are driving the

237 increase in GHG emissions globally. ${ }^{38,44}$ Variants of these methods have already been applied

238 in other studies. ${ }^{40,55,56}$

239 Table 1 here

240 Scenarios

241 The different value and modeling choices (two GHG accounting approaches, three GHG

242 metrics (and respective global emissions budgets), and two effort-sharing approaches) were

243 used to develop a set of $12(2 \times 3 \times 2)$ scenarios for each of the three climate thresholds (i.e. a

244 total of 36 scenarios). Table 2 shows the six production-based and six consumption-based

245 scenarios developed for the $1.5^{\circ} \mathrm{C}$ climate threshold (chosen as a baseline); similar scenarios

246 were developed for the remaining climate thresholds (see SI5 and SI6).

247 Table 2 here 
248 RESULTS AND DISCUSSION

249 New Zealand's GHG Emissions

250 In 2011, New Zealand's GHG emissions calculated using production- and consumption-

251 based accounting approaches were 84,192 and 81,505 kilotonnes ( $\mathrm{kt}$ ) $\mathrm{CO}_{2}$-eq, respectively, using GWP100 metrics (calculations are in SI2 and SI3). Since the production-based emissions were slightly $\left(=2,687 \mathrm{ktCO}_{2}\right.$-eq) higher than the consumption-based emissions, the country was a net GHG exporter in the given year.

Figure 1 presents New Zealand's production- and consumption-based emissions at sector level. According to the figure, for GWP100, half of New Zealand's production-based emissions were from agriculture; the contributions of other sectors were small when compared to agriculture, e.g., transport and equipment (17\%), electricity, gas and water (12\%), petroleum, chemical and non-metallic mineral products (4.5\%), and other services (5.1\%). These results clearly demonstrate that New Zealand has an unusual climate change profile compared with most other developed countries. Generally, energy production and/or energy-intensive sectors, and transport dominate the production-based GHG emissions of developed countries, while agriculture makes a relatively small contribution. ${ }^{9,} 13,16$ However, New Zealand is one of the largest food producing countries and exports around $85 \%$ of its total food production to the rest of the world. ${ }^{17,57}$

According to the consumption-based accounting approach (for GWP100), food and beverage was the largest contributor, representing a quarter (i.e. 26\%) of New Zealand's consumption-based emissions, followed by financial and trade-related services (20\%), other services (16\%), construction (8.5\%), transport and equipment (7.9\%), agriculture (5.5\%), and electricity, gas and waste (5.4\%). The seven sectors together contributed approximately $90 \%$ of New Zealand's consumption-based emissions in 2011. These consumption-based emissions 
272 were comparable (in terms of the emissions composition) to some other developed countries 273 such as Australia and the Netherlands. ${ }^{13}$

274 New Zealand's climate change results varied significantly, however, when an alternative 275 GHG metric and/or time horizon were selected, as shown in Figure 1. Using GWP20, New 276 Zealand's production- and consumption-based emissions were 159,804 and 140,660 $277 \mathrm{ktCO}_{2}$-eq respectively; these values are 73 and $90 \%$ higher than the results calculated using 278 GWP100. The increased results arise mainly due to the greater weighting given to the short279 lived $\mathrm{CH}_{4}$ gas in GWP20 rather than long-lived GHGs (compared with GWP100). A contrasting outcome was observed when GTP100, which gives a greater weighting to the long-lived $\mathrm{CO}_{2}$ gas, was used instead; according to Figure 1, New Zealand was a net GHG importer in 2011, given the production and consumption-based emissions were 32 to $40 \%$ lower than the emissions calculated using GWP100. Calculations are presented in the sections 4-6 of SI 2 and SI3.

In addition to the changes in total emissions when using different GHG metrics, notable changes were observed in terms of the relative contributions of some sectors to New Zealand's total emissions. For example, if GWP20 is used instead of GWP100, agriculture's contribution is $66 \%$ rather than $50 \%$, and transport and equipment's contribution is $9 \%$ rather than $17 \%$. The opposite occurs if GTP100 is applied as opposed to GWP100: agriculture's contribution is halved to $27 \%$ from $50 \%$, while transport and equipment's contribution is increased to $27 \%$ from $17 \%$. However, the total aggregated emissions for some of the other sectors remain (nearly) the same across the different GHG metrics (e.g., transport and equipment, electricity, gas and water, and metal products) for both production- and 
295

296

297

298

299

300

individual GHG emissions associated with different sectors, and the weightings assigned to different GHGs under each of the GHG metrics. Most of the GHG emissions of the transport and equipment sector are $\mathrm{CO}_{2}$, and non- $\mathrm{CO}_{2}$ GHG emissions are negligible. However, in contrast, agriculture's GHG emissions are primarily non- $\mathrm{CO}_{2}$ gases such as $\mathrm{CH}_{4}$ and $\mathrm{N}_{2} \mathrm{O}$ (for individual GHG emissions for each sector, see the section 7 of $\mathrm{SI} 2$ and SI3).

Figure 1 here 
New Zealand's Emissions Budgets: Influence of Choice of GHG Accounting Approach, GHG Metric and Effort-Sharing Approach

Table 3 presents the influence of the value and modeling choices in terms of the $\left(1.5^{\circ} \mathrm{C}\right)$ SoGEBs for New Zealand and its economic sectors. New Zealand's total production- and consumption-based SoGEBs (calculated using the GWP 100 metric and grandfathering approach) were 12,189 and $10,272 \mathrm{ktCO}_{2}-\mathrm{eq} \cdot \mathrm{yr}^{-1}$ respectively.

The SoGEBs of New Zealand and its economic sectors differed when an alternative GHG metric and/or effort-sharing approach were chosen. When the GHG metric was changed to GWP20, New Zealand's total production- and consumption-based SoGEBs increased by a factor 3.4 and 3.2 respectively. When the GHG metric was changed to GTP100, New Zealand's total production- and consumption-based SoGEBs varied by a factor 0.20 and 0.21 respectively. These notable variations are due to the different weightings assigned to different GHGs (under each GHG metric) when calculating the global emissions budget using the method of Bjørn and Hauschild. ${ }^{33}$ Alternatively, when the effort-sharing approach was changed (from grandfathering to economic value), New Zealand's total production- and consumption-based SoGEBs varied by a factor 0.77 and $0.99,0.61$ and 0.84 , and 0.98 and 1.2 for GWP 100, GWP20, and GTP100, respectively. These outcomes are explained by the underlying equity principle of each of the two effort-sharing approaches: the grandfathering approach assigns a SoGEB to a country based on the country's relative contribution to the global GHG emissions in a reference year, whereas the economic value-based approach assigns a SoGEB based on the country's economic contribution/expenditure. ${ }^{36,44}$

From a sector perspective, half of New Zealand's production-based SoGEB (for GWP100 and grandfathering, scenario S1) was assigned to the agriculture sector, and the SoGEBs assigned to other sectors were small (17\% or less). The largest share of New Zealand's consumption-based SoGEB (for GWP100 and grandfathering, S7) was assigned to the food 
326 and beverage sector (26\%), and the SoGEBs assigned to other sectors were small (18\% or less).

327 In scenarios where the GHG metric was changed to GWP20, sector SoGEBs varied by a factor

328 (up to) 5.1 (mining and quarrying in S2) and 4.3 (agriculture in S8), for the production- and 329 consumption-based accounting approaches, respectively. When the GHG metric was changed 330 to GTP100, sector SoGEBs varied by a factor of 0.07 (mining and quarrying in S3) to 0.32 (metal 331 products in S3), and 0.12 (agriculture in S9) to 0.31 (electricity, gas and water in S9) 332 respectively. In scenarios where the effort-sharing approach was changed, sector SoGEBs 333 showed significant variations; for example, sector SoGEBs in S5 (as opposed to S1) differed by 334 a factor of 0.091 (agriculture) to 34 (miscellaneous). 


\section{New Zealand's Emissions Budgets: Influence of Additional Value and Modeling Choices}

In addition to the above-discussed choices, the influence of the choice of global climate threshold, method for calculating the global emissions budget, and reference year for the grandfathering approach, were also evaluated.

Regarding the choice of global climate threshold, if $2^{\circ} \mathrm{C}$ was used as opposed to $1.5^{\circ} \mathrm{C}$, New Zealand's total production- and consumption-based SoGEBs increased by a factor 1.3. Alternatively, if $1 \mathrm{Wm}^{-2}$ planetary boundary threshold was used instead, New Zealand's total production- and consumption-based SoGEBs varied by a factor 0.53 .

The sector-level analysis showed the same variations when an alternative climate threshold was chosen (for $2^{\circ} \mathrm{C}$ and $1 \mathrm{Wm}^{-2}$ results, see $\mathrm{SI} 5$ and SI6, respectively). These variations are explained by the notable differences between the global emissions budgets calculated for each climate threshold, e.g., 3.6, 5.1, and $6.8 \mathrm{GtCO}_{2}$-eq $\cdot \mathrm{yr}^{-1}$ for $1 \mathrm{Wm}^{-2}, 1.5$, and $2{ }^{\circ} \mathrm{C}$ climate thresholds, respectively (using GWP100).

To calculate the global emissions budget, the method proposed by Bjørn and Hauschild ${ }^{33}$ was used in this study. If Doka's ${ }^{32}$ method was applied to calculate the global emissions budget, the $1.5^{\circ} \mathrm{C}$ global emissions budget was a factor 4.1 higher than the budget used in our analysis. Therefore, the SoGEBs of New Zealand and its sectors increased by a factor 4.1 (see the section 5 of SI7).

Lastly, the influence of the choice of reference year for the grandfathering approach was examined by re-running the analysis for the year 2011 based on an alternative reference year (2005 instead of 2000). The analysis showed a moderate influence at the country level; New Zealand's total production- and consumption-based SoGEBs varied by a factor of 0.91 (scenario S2) to 0.93 (S3) and 1.07 (S8) to 1.14 (S9), respectively. The sector-level analysis, however, showed significant variations in terms of the SoGEBs; they varied by a factor of 0.79 
359 to 5.1 and 0.85 to 1.5 for production- and consumption-based approaches (see the sections 3604 and 5 of SI4). These outcomes are due to the differences in the climate change profile of 361 New Zealand in the years 2000 and 2005. 


\section{New Zealand's Occupied Shares of the Emissions Budgets}

Tables 4 and 5 show the influence of the value and modeling choices in terms of occupied shares of the $1.5^{\circ} \mathrm{C}$ global emissions budget for all the economic sectors of New Zealand, for production and consumption-based accounting approaches respectively. These outcomes provide (at least) five key insights.

Firstly, New Zealand exceeded its SoGEBs in all scenarios, irrespective of the choice of GHG accounting approach. The exceedances varied by a factor of 3.9 to 21 and 4.2 to 24 , across the production- and consumption-based approaches respectively.

Secondly, all the economic sectors exceeded their SoGEBs in the grandfathering approach (for both production and consumption). Exceedances, however, varied significantly with regard to the choice of GHG metric. For example, when production-based emissions (using GWP100, scenario S1 in Table 4) were compared with the respective SoGEBs, the exceedances varied by a factor of 5.7 (petroleum, chemical and non-metallic mineral products) to 19 (fishing). When GWP20 was applied instead (S2), the exceedances varied by a factor of 3.4 (petroleum, chemical and non-metallic mineral products) to 19 (fishing). In contrast, when GTP100 was applied (S3), the exceedances varied by a factor of 17 (petroleum, chemical and non-metallic mineral products) to 34 (fishing). These large variations are explained by the influence of the choice of GHG metric in calculating the GHG emissions of New Zealand's sectors and the global emissions budget (whose shares were subsequently assigned to each sector).

Thirdly, although all 16 sectors exceeded their SoGEBs under the grandfathering approach (for both production and consumption), some sectors were within their SoGEBs when using the economic value-based sharing approach. According to Tables 4 and 5, three sectors were within their SoGEBs for the production-based accounting approach (financial 
and trade services, miscellaneous, and fishing), while no sector was within its SoGEB for the consumption-based accounting approach. Furthermore, unlike the grandfathering approach, the exceedances in the economic value sharing approach varied remarkably; they were in the range of factor 1.1 (wood and paper in S5) to 149 (electricity, gas and water in S6) and 2.0 (electrical and machinery in S11) to 666 (fishing in S12), for the production- and consumptionbased accounting approaches, respectively. These large variations are due to the widely different GHG emissions and economic contributions (and expenditures) of these sectors. For example, in 2011, the production-based GHG emissions of agriculture were $41,913 \mathrm{ktCO}_{2}$-eq, which was approximately 25 times the emissions of the financial and trade services sector.

On the other hand, the economic contribution of the agriculture sector was equivalent to US\$14 billion, which was approximately a quarter of the economic contribution of the financial and trade services sector (US\$54 billion, see Table 4). As a result, the financial and in S5) being unsustainable for the production-based accounting approach (see the section 1 of SI8). These variations in the exceedances are due to the notable differences between the global emissions budgets estimated for each climate threshold. 
410 Lastly, when the choice of reference year for the grandfathering approach was examined, 411 the analysis showed a moderate influence at the country level: the production- and 412 consumption-based exceedances varied by a factor of 1.08 (scenario S3) to 1.10 (S2) and 0.88 413 (S9) to 0.94 (S8) respectively. The sector-level analysis, however, showed significant variations 414 in exceedances: the production-based exceedances differed by a factor of 0.20 (fishing in S2) 415 to 1.27 (petroleum, chemical and non-metallic mineral products in S3), whereas 416 consumption-based exceedances varied by a factor of 0.67 (miscellaneous in S9) to 1.18 417 (agriculture in S8) (see the section 2 of SI8). These outcomes are primarily due to the 418 differences in the climate change profile of New Zealand in 2000 and 2005.

$419 \quad$ Tables 4 and 5 here 


\section{Research Implications for Setting Emissions Budgets for Anthropogenic Systems}

For both GHG accounting approaches, the largest source of uncertainty in New Zealand's

SoGEBs arose from the choice of method for calculating the global emissions budget (a factor 4.1), followed by the choice of GHG metric ( 0.20 to 3.4), the choice of climate threshold ( 0.53 to 1.3 ), the choice of effort-sharing approach (0.61 to 1.2$)$, and the choice of reference year for the grandfathering approach (0.91 to 1.1).

The influence of these choices, however, varied notably with regard to New Zealand's sector SoGEBs. For each GHG accounting approach, the largest source of uncertainty arose from the choice of effort-sharing approach (0.031 to 34), followed by the choice of GHG metric $(0.072$ to 5.1$)$, the choice of reference year for the grandfathering approach $(0.79$ to 5.1), the choice of method for calculating the global emissions budget (4.1), and the choice of climate threshold (0.53 to 1.3 ).

Taken together, the results at both national and sector level indicate, in contrast to the current focus on choosing either a 1.5 or $2^{\circ} \mathrm{C}$ climate threshold, the importance of considering other value and modeling choices when setting emissions budgets for anthropogenic systems.

Regarding the choice of GHG metric, the International Life Cycle Initiative recommends to carry out a sensitivity analysis with the GWP20 and GTP100 metrics (in addition to GWP100) to ensure that the conclusions about the ranking of different anthropogenic systems are robust regardless of the choice of GHG metric. ${ }^{22-24,58}$ The results of our analysis emphasise the relevance of this guidance. However, until recently, no similar agreement has been reached regarding the choice of effort-sharing approach; while some recommend sharing the global emissions budget equally among the world population, others suggest using the grandfathering or economic value-based approaches. ${ }^{36,38,40}$ Our results suggest that guidance on this choice should be a priority, given it is the largest source of uncertainty in the 
sector SoGEBs. The reference year for the grandfathering approach and method for calculating the global emissions budget are also both significant sources of uncertainty.

446 Therefore, a consensus should be developed regarding these choices.

447 The study has additional implications for research on method development for setting 448 GHG emissions budgets and policymaking. The proposed methodological framework can be considered as a complementary approach to the sectoral decarbonization approach (SDA) developed under the Science Based Targets initiative. ${ }^{59,60}$ SDA transforms the sectoral emission pathways of the International Energy Agency into sectoral intensity pathways using economic or physical indicators, and then translates these into individual company intensity pathways. Although SDA is currently being used mostly for setting emissions (only $\mathrm{CO}_{2}$ ) budgets for homogenous economic sectors (and companies) such as power generation, metal production, and cement production, it is not suited for heterogeneous sectors such as agriculture and construction whose GHGs and product categories are quite diverse. ${ }^{60}$ These limitations are, however, addressed by the proposed framework which accounts for all GHGs (a total of 24), assigns a share of the global emission budget to each sector and subsequently, informs the required levels of emission reduction for all the sectors of a country. potentially catalyse innovation and support investment in low-emissions activities and technologies, ${ }^{16,61,62}$ it could also have perverse consequences. For example, New Zealand's agriculture is recognized as relatively carbon-efficient compared with many other countries. ${ }^{24,}$

57 A requirement for costly mitigation efforts could result in the shifting of agricultural production to some other countries with poor agricultural practices and higher GHG emissions per unit of production, leading to a global increase in GHG emissions. It may be preferable, instead, to offset New Zealand's agricultural GHG emissions by imposing more 
stringent targets on other sectors where mitigation efforts may be easier to implement and more cost-effective (e.g., electricity, gas and water, and transport and equipment). This could

470 be facilitated by the adaptation of the existing New Zealand emissions trading scheme, which 471 currently excludes agricultural $\mathrm{CH}_{4}$ emissions until 2025 , by including all the GHGs of all 472 economic sectors. ${ }^{63,64}$

473 To mitigate both production- and consumption-based emissions, a range of climate 474 policies have already been proposed and are being deployed across the world, $16,61,62,65$ 475 including policies that focus on fuel efficiency improvements in passenger cars, uptake of 476 public transport, energy retrofits in buildings, and change of dietary patterns. ${ }^{66-69}$ However, 477 many of these policies have turned out to be less effective than predicted due to rebound 478 effects where consumers substitute decreased consumption of one good or service by 479 increased consumption of other goods and/or services. ${ }^{61,67,68}$ To be effective, setting a 480 comprehensive range of consumption-based emissions budgets at national level, as well as 481 per capita emissions budgets for different product consumption categories, could provide a 482 better basis to deal with rebound effects. 


\section{Research Limitations and Future Work}

This study, for the first time, examined the influence of alternative value or modeling choices on setting emissions budgets for anthropogenic systems, taking New Zealand's economic sectors as a case study. The choices included: two GHG accounting approaches, three GHG metrics, three global climate thresholds, two methods for calculating the global carbon budget, two effort-sharing approaches, and two reference years for the grandfathering approach. There are additional alternatives for each of these choices ${ }^{5,36,38,70}$ that were not examined but whose influence on the final results could be investigated in future analyses.

There is interest amongst policymakers in setting emissions budgets for individual GHGs (such as $\mathrm{CO}_{2}, \mathrm{CH}_{4}$, and $\mathrm{N}_{2} \mathrm{O}$ budgets). ${ }^{48,71,72}$ Future work could explore how these individual emission budgets can be assigned to different economic sectors given that a $\mathrm{CO}_{2}$ budget is relevant for sectors like transport and equipment, and metal products, while $\mathrm{CH}_{4}$ and $\mathrm{N}_{2} \mathrm{O}$ budgets are more relevant for agriculture.

Another topic for future research concerns how the proposed methodological framework presented in this study can be adapted to set emissions budgets that also account for discrete future activities in economic sectors. In that context, it is crucial to understand the differences between static and dynamic approaches to estimating global emissions budgets. In this study, a static approach was applied; as a result, the global emissions budget for any given year throughout the $21^{\text {st }}$ century is the same. However, this approach does not represent the timespecific societal transitions to a low-carbon society that could take place in the future. On the other hand, dynamic approaches, such as the IPCC's Representative Concentration Pathways $^{25}$ and the latest Shared Socio-economic Pathways ${ }^{31}$ represent these time-specific changes. For example, these scenarios project that the global $\mathrm{CO}_{2}$ emissions involve a sharp 
507 decrease to net zero by around 2050 and 2075, for the 1.5 and $2{ }^{\circ} \mathrm{C}$ climate thresholds, 508 respectively. ${ }^{31}$

509 To that end, using a dynamic approach, ${ }^{73}$ Chandrakumar et al. have proposed a method 510 for setting emissions budgets that accounts for both the current New Zealand residential 511 housing stock and time-specific construction of additional buildings up to $2050 .{ }^{56,74}$ This type 512 of study is likely to be particularly relevant for long-lived products and services whose GHG 513 emissions during use are largely "locked-in" at the design or manufacturing stage, and where 514 significant modifications are difficult once the product or service has entered its use stage. 515 Examples include vehicles, energy generation facilities, and waste management 516 infrastructure. 
517 Table 1. Overview of effort-sharing approaches, underlying equity principles and equations for calculating the share of the global emissions budget available for each

518 economic sector

\begin{tabular}{|c|c|c|c|}
\hline Effort-sharing approach & GHG Accounting approach & Equity principle $^{36}$ & Equation \\
\hline Grandfathering (GF) & Production & Sovereignty & $\begin{array}{l}\mathrm{aS}_{\mathrm{ESA}}=\frac{\mathrm{GHG}_{\mathrm{Pro}, \mathrm{X}}}{\mathrm{GHG}_{\text {World }}} \\
\text { Where } \mathrm{aS}_{\mathrm{ESA}} \text { is the share of the global emissions budget assigned to the } \\
\text { studied sector } \mathrm{X} \text { of a country. } \mathrm{GHG}_{\text {Pro, } \mathrm{X}} \text { is the production-based } \mathrm{GHG} \\
\text { emissions of sector } \mathrm{X} \text {, whereas } \mathrm{GHG}_{\text {World }} \text { is the global } \mathrm{GHG} \text { emissions. }\end{array}$ \\
\hline $\begin{array}{l}\text { Economic value: gross } \\
\text { value added (GVA) }\end{array}$ & Production & Capability & $\begin{array}{l}\mathrm{aS}_{\mathrm{ESA}}=\frac{\mathrm{GVA} \mathrm{A}_{\mathrm{X}}}{\mathrm{GVA}_{\text {World }}} \\
\text { Where GVA } \mathrm{is} \text { gross value added by sector } \mathrm{X} \text {, and GVA }{ }_{\text {World }} \text { is the total gross } \\
\text { value added in the world. }\end{array}$ \\
\hline Grandfathering (GF) & Consumption & Sovereignty & $\begin{array}{l}\mathrm{aS}_{\mathrm{ESA}}=\frac{\mathrm{GHG}_{\mathrm{Con}, \mathrm{X}}}{\mathrm{CF}_{\text {World }}} \\
\text { Where } \mathrm{GHG}_{\text {Con }, \mathrm{X}} \text { is the consumption-based GHG emissions of sector } \mathrm{X} \text {. }\end{array}$ \\
\hline $\begin{array}{l}\text { Economic value: final } \\
\text { consumption expenditure } \\
\text { (FCE) }\end{array}$ & Consumption & Need & $\begin{array}{l}\mathrm{aS}_{\mathrm{ESA}}=\frac{\mathrm{FCE}_{\mathrm{X}}}{\mathrm{FCE}_{\text {World }}} \\
\text { Where } \mathrm{FCE} \text { is the money spent by consumers on sector } \mathrm{X} \text {, and } \mathrm{FCE} \mathrm{W}_{\text {World }} \text { is the } \\
\text { total final expenditure of the world. }\end{array}$ \\
\hline
\end{tabular}


519 Table 2. Underlying value choices and parameters for the 12 scenarios proposed for the $1.5^{\circ} \mathrm{C}$ climate threshold

\begin{tabular}{|c|c|c|c|c|}
\hline \multirow{2}{*}{$\begin{array}{l}\text { GHG accounting } \\
\text { approach }\end{array}$} & \multirow[t]{2}{*}{ Scenarios $^{\mathrm{a}}$} & \multicolumn{3}{|l|}{ Value choices } \\
\hline & & Effort-sharing approach & GHG metric & Global emissions budget ${ }^{a}\left(\mathrm{GtCO}_{2}-\mathrm{eq} \cdot \mathrm{yr}^{-1}\right)$ \\
\hline \multirow[t]{5}{*}{ Production } & S1-1.5DC,GWP100,GF & \multirow[t]{2}{*}{ Grandfathering $^{\mathrm{b}}$} & GWP100 & 5.1 \\
\hline & S2-1.5DC,GWP20,GF & & GWP20 & 13.8 \\
\hline & S4-1.5DC,GWP100,GVA & \multirow[t]{3}{*}{ Economic value: gross value added ${ }^{c}$} & GWP100 & 5.1 \\
\hline & S5-1.5DC,GWP20,GVA & & GWP20 & 13.8 \\
\hline & S6-1.5DC,GTP100,GVA & & GTP100 & 1.3 \\
\hline \multirow[t]{6}{*}{ Consumption } & S7-1.5DC,GWP100,GF & \multirow[t]{3}{*}{ Grandfathering $^{b}$} & GWP100 & 5.1 \\
\hline & S8-1.5DC,GWP20,GF & & GWP20 & 13.8 \\
\hline & S9-1.5DC,GTP100,GF & & GTP100 & 1.3 \\
\hline & S10-1.5DC,GWP100,GVA & \multirow{3}{*}{$\begin{array}{l}\text { Economic value: final consumption } \\
\text { expenditure }^{c}\end{array}$} & GWP100 & 5.1 \\
\hline & S11-1.5DC,GWP20,GVA & & GWP20 & 13.8 \\
\hline & S12-1.5DC,GTP100,GVA & & GTP100 & 1.3 \\
\hline
\end{tabular}

a The $1.5^{\circ} \mathrm{C}$ global emissions budgets calculated for each of the three GHG metrics, according to the method proposed by Bjørn and Hauschild. ${ }^{33}$

${ }^{b}$ For the grandfathering approach, the year 2000 was chosen as the reference year. The GHG emissions of the New Zealand economic sectors in 2000 were calculated using the Eora-based environmentally-extended MRIO analysis ${ }^{52}$ and all 24 GHGs were aggregated using the three GHG metrics respectively, as was already done for 2011. The uncertainty related to this choice was assessed by re-running the analysis based on an alternative reference year (i.e. 2005) (results are in the SI).

${ }^{c}$ Economic indicator values (for gross value added and final consumption expenditure) of New Zealand and the entire world were sourced from the Eora26 MRIO database. ${ }^{49,50}$ 
Table 3. The influence of the value and modeling choices in terms of the $1.5^{\circ} \mathrm{C}$ global emissions budget shares for New Zealand and its economic sectors

\begin{tabular}{|c|c|c|c|c|c|c|c|c|c|c|c|c|}
\hline \multirow[t]{2}{*}{ Sectors } & \multicolumn{6}{|c|}{$\begin{array}{l}\text { Production-based emissions budget shares }{ }^{\mathrm{a}} \\
\left(\mathrm{ktCO}_{2}-\mathrm{eq} \cdot \mathrm{yr}^{-1}\right)\end{array}$} & \multicolumn{6}{|c|}{$\begin{array}{l}\text { Consumption-based emissions budget shares }{ }^{\mathrm{a}} \\
\left(\mathrm{ktCO}_{2}-\mathrm{eq} \cdot \mathrm{yr}^{-1}\right)\end{array}$} \\
\hline & 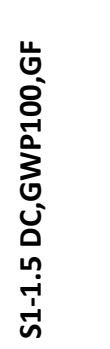 & 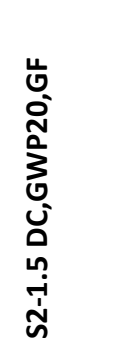 & 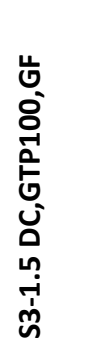 & 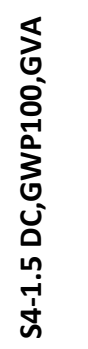 & 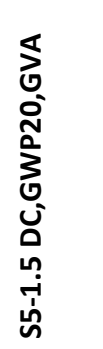 & 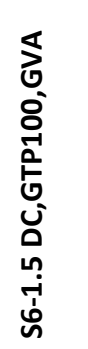 & 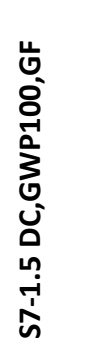 & 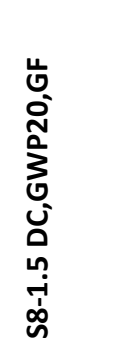 & 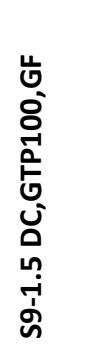 & 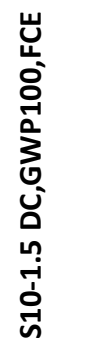 & 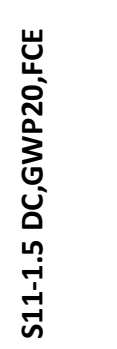 & 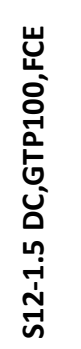 \\
\hline Agriculture & 6079 & 27981 & 629 & 944 & 2542 & 236 & 811 & 3529 & 100 & 86 & 232 & 22 \\
\hline Transport \& equipment & 2111 & 3912 & 661 & 627 & 1689 & 157 & 873 & 1900 & 252 & 796 & 2142 & 199 \\
\hline Electricity, Gas \& Water & 1473 & 2709 & 464 & 270 & 726 & 67 & 536 & 1042 & 164 & 158 & 426 & 40 \\
\hline $\begin{array}{l}\text { Petroleum, Chemical \& Non-Metallic } \\
\text { Mineral Products }\end{array}$ & 669 & 1333 & 202 & 237 & 637 & 59 & 312 & 854 & 77 & 282 & 760 & 71 \\
\hline Services: Others & 536 & 2323 & 70 & 2014 & 5421 & 503 & 1530 & 5047 & 314 & 2816 & 7579 & 704 \\
\hline Metal Products & 363 & 644 & 117 & 141 & 379 & 35 & 43 & 102 & 12 & 28 & 74 & 6.9 \\
\hline Food \& Beverages & 235 & 436 & 74 & 340 & 916 & 85 & 2736 & 10309 & 458 & 720 & 1937 & 180 \\
\hline Mining \& Quarrying & 205 & 1056 & 15 & 121 & 327 & 30 & 32 & 99 & 7.2 & 17 & 45 & 4.1 \\
\hline Construction & 153 & 283 & 48 & 459 & 1236 & 115 & 882 & 2389 & 219 & 1069 & 2877 & 267 \\
\hline Services: Financial \& Trade & 158 & 306 & 48 & 3561 & 9586 & 890 & 1954 & 5855 & 443 & 3273 & 8811 & 818 \\
\hline Wood \& Paper & 95 & 177 & 30 & 301 & 811 & 75 & 157 & 531 & 31 & 127 & 343 & 32 \\
\hline Electrical \& Machinery & 64 & 127 & 19 & 144 & 386 & 36 & 350 & 924 & 89 & 670 & 1803 & 167 \\
\hline Textiles \& Wearing Apparel & 29 & 54 & 9.2 & 95 & 256 & 24 & 194 & 618 & 41 & 201 & 542 & 50 \\
\hline Other Manufacturing & 14 & 26 & 4.3 & 49 & 131 & 12 & 102 & 279 & 25 & 132 & 354 & 33 \\
\hline Miscellaneous & 3.2 & 6.2 & 1.0 & 78 & 209 & 19 & 44 & 125 & 11 & 110 & 297 & 28 \\
\hline Fishing & 2.2 & 4.4 & 0.68 & 35 & 94 & 8.8 & 14 & 41 & 3.5 & 0.47 & 1.3 & 0.12 \\
\hline Total-New Zealand & 12189 & 41378 & 2392 & 9417 & 25347 & 2353 & 10572 & 33645 & 2246 & 10485 & 28221 & 2620 \\
\hline
\end{tabular}

aDescription of the scenarios is given in Table 2. The results are rounded to two significant digits. Calculations are available in the sections 1 and 2 of SI4. 


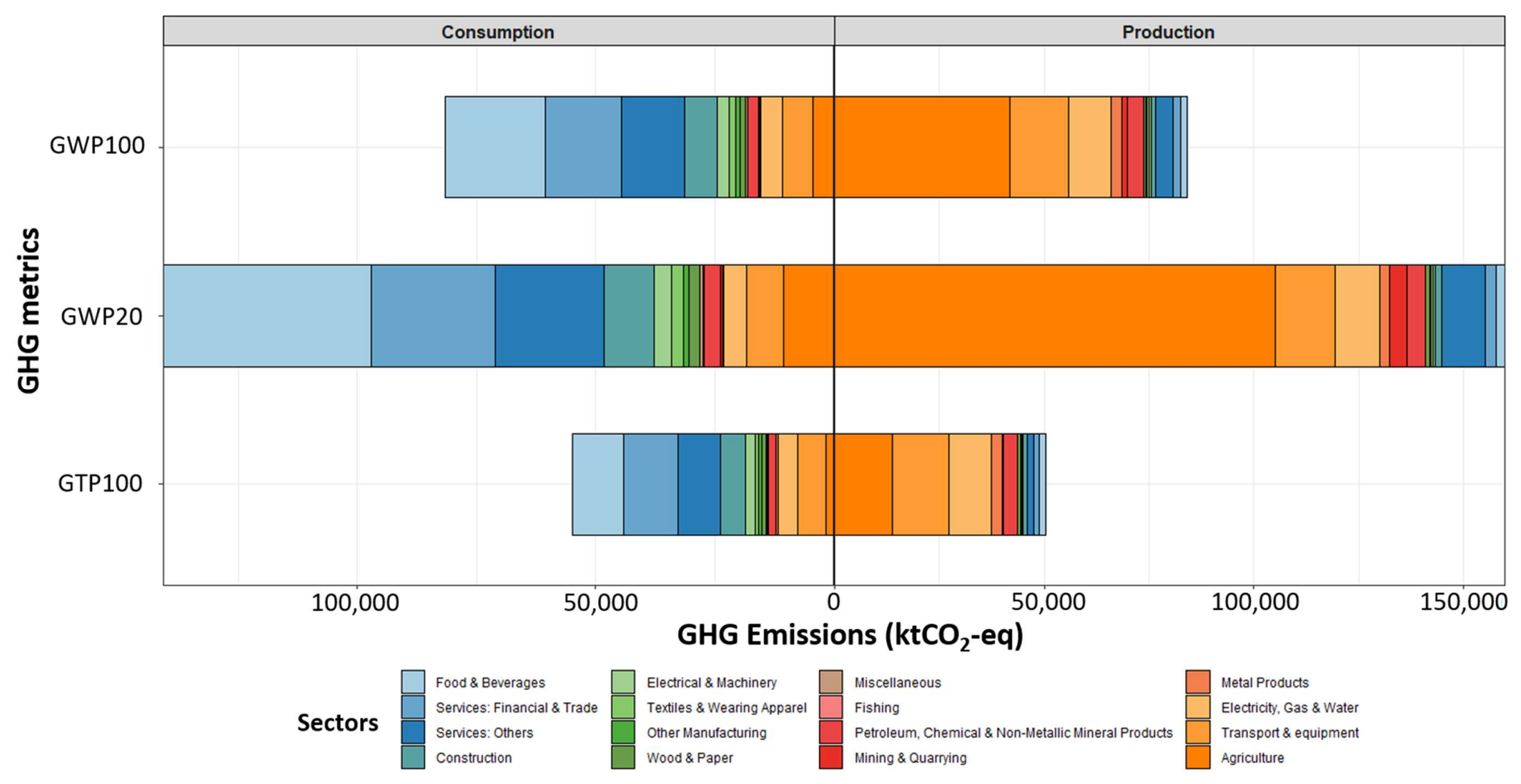

Figure 1. Contributions of 16 economic sectors to New Zealand's production- and consumption-based GHG emissions for the year 2011, calculated using three different 
Table 4. The occupied shares of the $1.5^{\circ} \mathrm{C}$ global emissions budget (SoGEB) by each sector for twelve scenarios (in \%) for the production-based accounting approach. If occupied share of the global emissions budget by a sector for a chosen effort-sharing approach (occSoGEB $\mathrm{X}_{\mathrm{X}, \mathrm{ESA}}$ ) is greater than $100 \%$, sector $\mathrm{X}$ is unsustainable in absolute terms for the climate change impact category. The values in the figure are rounded off to the first decimal point. See the SI for the actual values. Description of the scenarios is given in Table 2. Colors indicate scenarios where the occSoGEB $\mathrm{X}_{\mathrm{EESA}}$ is less than $100 \%$ (green), $\geq 100 \%$ (yellow), $>1500 \%$ (orange), and $>4000 \%$ (red). The reader is referred to the online version of the article for the interpretation of the references to color in the table. 


\begin{tabular}{|c|c|c|c|c|c|c|c|c|c|c|}
\hline \multirow[t]{3}{*}{ Sector } & \multirow{2}{*}{\multicolumn{3}{|c|}{$\begin{array}{l}\text { Production-based GHG } \\
\text { emissions }\left(\mathrm{ktCO}_{2} \mathrm{eq}\right)\end{array}$}} & \multirow{3}{*}{$\begin{array}{l}\text { Gross value } \\
\text { added } \\
(\times 1000 \text { US\$) }\end{array}$} & \multicolumn{6}{|c|}{ Occupied share of the global emissions budget (\%) } \\
\hline & & & & & \multicolumn{6}{|l|}{ Scenarios } \\
\hline & $\begin{array}{l}8 \\
0 \\
0 \\
0 \\
0\end{array}$ & 足 & $\begin{array}{l}8 \\
0 \\
0 \\
0\end{array}$ & & 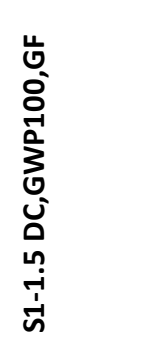 & 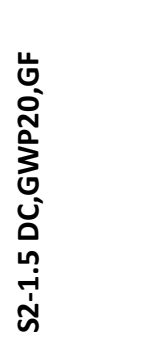 & 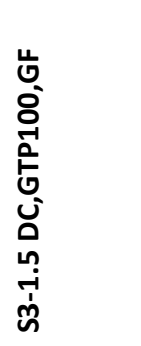 & 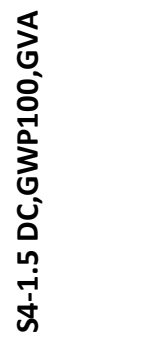 & 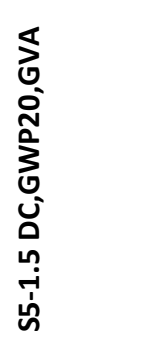 & 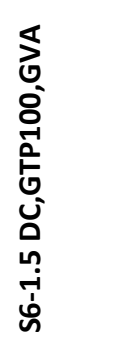 \\
\hline Agriculture & 41913 & 105089 & 13717 & 25395000 & 689 & 376 & 2182 & 4439 & 4135 & 5813 \\
\hline Transport \& equipment & 13934 & 14338 & 13712 & 19730900 & 660 & 366 & 2074 & 2221 & 849 & 8745 \\
\hline Electricity, Gas \& Water & 10183 & 10398 & 10076 & 9764300 & 692 & 384 & 2173 & 3773 & 1431 & 14938 \\
\hline Petroleum, Chemical \& Non-Metallic Mineral Products & 4256 & 10141 & 1658 & 11647000 & 566 & 337 & 1698 & 1599 & 704 & 5790 \\
\hline Services: Others & 3782 & 4485 & 3423 & 64104360 & 794 & 436 & 2373 & 211 & 187 & 329 \\
\hline Metal Products & 2409 & 2408 & 2435 & 7624400 & 664 & 374 & 2073 & 1709 & 635 & 6913 \\
\hline Food \& Beverages & 1702 & 2820 & 1143 & 28457000 & 707 & 463 & 2019 & 490 & 220 & 1752 \\
\hline Mining \& Quarrying & 1666 & 2015 & 1490 & 3649700 & 706 & 385 & 2137 & 1194 & 1245 & 1042 \\
\hline Construction & 1449 & 4069 & 316 & 24574000 & 764 & 555 & 2019 & 254 & 127 & 845 \\
\hline Services: Financial \& Trade & 1168 & 1571 & 969 & 113114200 & 1076 & 921 & 2369 & 48 & 29 & 128 \\
\hline Wood \& Paper & 699 & 890 & 603 & 14791000 & 732 & 504 & 2017 & 232 & 110 & 801 \\
\hline Electrical \& Machinery & 513 & 720 & 401 & 7159600 & 799 & 566 & 2112 & 358 & 186 & 1117 \\
\hline Textiles \& Wearing Apparel & 277 & 435 & 198 & 4536500 & 942 & 799 & 2154 & 292 & 170 & 836 \\
\hline Other Manufacturing & 154 & 260 & 102 & 2460400 & 1116 & 1018 & 2346 & 317 & 199 & 836 \\
\hline Miscellaneous & 43 & 83 & 24 & 2790188 & 1372 & 1339 & 2486 & 56 & 40 & 123 \\
\hline Fishing & 42 & 82 & 23 & 1591000 & 1894 & 1864 & 3351 & 121 & 87 & 261 \\
\hline Total-New Zealand & 84192 & 159804 & 50290 & 341389548 & 691 & 386 & 2103 & 894 & 630 & 2137 \\
\hline
\end{tabular}


Table 5. The occupied shares of the $1.5^{\circ} \mathrm{C}$ global emissions budget (SOGEB) by each sector for twelve scenarios (in \%) for the consumption-based accounting approach. If occupied share of the global emissions budget by a sector for a chosen effort-sharing approach (occSoGEB $B_{x, E S A}$ ) is greater than $100 \%$, sector $\mathrm{X}$ is unsustainable in absolute terms for the climate change impact category. The values in the figure are rounded off to the first decimal point. See the SI for the actual values. Description of the scenarios is given in Table 2. Colors indicate scenarios where the occSoGEB $\mathrm{B}_{\mathrm{X}, \mathrm{ESA}}$ is less than $100 \%$ (green), $\geq 100 \%$ (yellow), $>1500 \%$ (orange), and $>4000 \%$ (red). The reader is referred to the online version of the article for the interpretation of the references to color in the table. 


\begin{tabular}{|c|c|c|c|c|c|c|c|c|c|c|}
\hline \multirow[t]{3}{*}{ Sector } & \multicolumn{3}{|c|}{$\begin{array}{l}\text { Consumption-based GHG } \\
\left.\text { emissions (ktCO }{ }_{2} \mathrm{eq}\right)\end{array}$} & \multirow{3}{*}{$\begin{array}{l}\text { Final } \\
\text { consumption } \\
\text { expenditure } \\
(\times 1000 \text { US\$) }\end{array}$} & \multicolumn{6}{|c|}{ Occupied share of the global emissions budget (\%) } \\
\hline & \multirow[b]{2}{*}{ 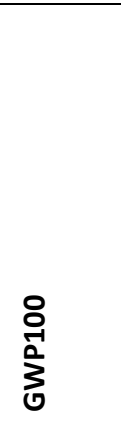 } & \multirow[b]{2}{*}{$\sum_{\substack{0 \\
\vdots}}^{0}$} & \multirow[b]{2}{*}{ O } & & \multicolumn{6}{|c|}{ Scenarios } \\
\hline & & & & & 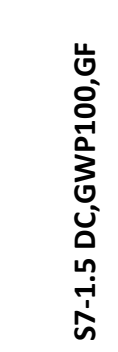 & 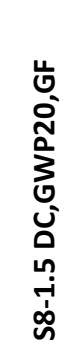 & 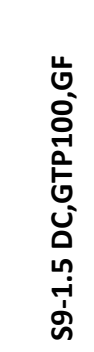 & 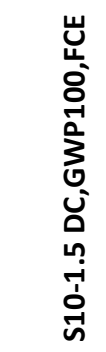 & 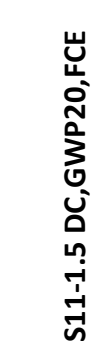 & 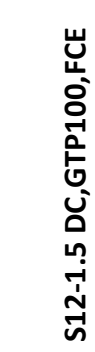 \\
\hline Agriculture & 4482 & 10706 & 1703 & 1365343 & 552 & 303 & 1708 & 5204 & 4618 & 7910 \\
\hline Transport \& equipment & 6440 & 7699 & 5859 & 12614298 & 738 & 405 & 2324 & 809 & 359 & 2946 \\
\hline Electricity, Gas \& Water & 4426 & 4709 & 4295 & 2506447 & 826 & 452 & 2611 & 2799 & 1107 & 10870 \\
\hline Petroleum, Chemical \& Non-Metallic Mineral Products & 2182 & 3367 & 1647 & 4473072 & 700 & 394 & 2146 & 773 & 443 & 2335 \\
\hline Services: Others & 13080 & 22801 & 8745 & 44636098 & 855 & 452 & 2788 & 465 & 301 & 1243 \\
\hline Metal Products & 314 & 404 & 274 & 436961 & 721 & 395 & 2273 & 1137 & 545 & 3980 \\
\hline Food \& Beverages & 20989 & 43623 & 10859 & 11406966 & 767 & 423 & 2371 & 2917 & 2252 & 6038 \\
\hline Mining \& Quarrying & 228 & 417 & 146 & 262621 & 709 & 420 & 2035 & 1377 & 936 & 3515 \\
\hline Construction & 6919 & 10461 & 5315 & 16944539 & 785 & 438 & 2424 & 647 & 364 & 1990 \\
\hline Services: Financial \& Trade & 15953 & 26032 & 11408 & 51891302 & 816 & 445 & 2575 & 487 & 295 & 1394 \\
\hline Wood \& Paper & 1236 & 2256 & 779 & 2017834 & 786 & 425 & 2510 & 971 & 658 & 2449 \\
\hline Electrical \& Machinery & 2496 & 3657 & 1967 & 10620564 & 713 & 396 & 2218 & 373 & 203 & 1175 \\
\hline Textiles \& Wearing Apparel & 1356 & 2372 & 898 & 3189208 & 699 & 384 & 2185 & 674 & 438 & 1786 \\
\hline Other Manufacturing & 841 & 1281 & 642 & 2085443 & 827 & 460 & 2562 & 640 & 362 & 1953 \\
\hline Miscellaneous & 458 & 709 & 344 & 1749190 & 1031 & 566 & 3225 & 415 & 239 & 1247 \\
\hline Fishing & 106 & 166 & 79 & 7502 & 735 & 408 & 2276 & 22374 & 13001 & 66590 \\
\hline Total-New Zealand & 81505 & 140660 & 54960 & 166207389 & 771 & 418 & 2447 & 777 & 498 & 2097 \\
\hline
\end{tabular}




\section{ACKNOWLEDGEMENTS}

537 Chanjief Chandrakumar acknowledges the Massey University Doctoral Scholarship. The 538 authors thank Joel Cornelio and Abhipray Paturkar of Massey University for graphic design 539 and layout support.

\section{SUPPORTING INFORMATION}

541 Global emissions budget calculation methods and emissions budgets for three different 542 climate thresholds; production- and consumption-based GHG emissions of New Zealand 543 calculated at a sector level using different GHG metrics; global emissions budget shares assigned to each of the New Zealand sectors; influence of each of the value/modeling choices considered in this study.

\section{REFERENCES}

$547 \quad$ 1. Lenton, T. M.; Held, H.; Kriegler, E.; Hall, J. W.; Lucht, W.; Rahmstorf, S.; Schellnhuber, H. J. Tipping elements in the Earth's climate system. Proc. Natl. Acad. Sci. 2008, 105, (6), 1786-1793.

$5492 . \quad$ Levermann, A.; Bamber, J. L.; Drijfhout, S.; Ganopolski, A.; Haeberli, W.; Harris, N. R. P.; Huss, M.; Krüger, 550 K.; Lenton, T. M.; Lindsay, R. W.; Notz, D.; Wadhams, P.; Weber, S. Potential climatic transitions with profound 551 impact on Europe. Clim. Change 2012, 110, (3), 845-878.

$552 \quad$ 3. Allen, M. R.; Fuglestvedt, J. S.; Shine, K. P.; Reisinger, A.; Pierrehumbert, R. T.; Forster, P. M. New use of 553 global warming potentials to compare cumulative and short-lived climate pollutants. Nat. Clim. Change 2016, 6, 554773.

555 4. Shine, K. P.; Fuglestvedt, J. S.; Hailemariam, K.; Stuber, N. Alternatives to the Global Warming Potential 556 for Comparing Climate Impacts of Emissions of Greenhouse Gases. Clim. Change 2005, 68, (3), $281-302$.

$557 \quad 5 . \quad J \emptyset r g e n s e n$, S. V.; Hauschild, M. Z.; Nielsen, P. H. Assessment of urgent impacts of greenhouse gas 558 emissions-the climate tipping potential (CTP). Int. J. Life Cycle Assess. 2014, 19, (4), 919-930.

$5596 . \quad$ Chandrakumar, C. Evaluation of New Zealand's Absolute Environmental Sustainability Performance: 560 Development and Application of a Method to Assess the Climate Change Performance of New Zealand's 561 Economic Sectors; Massey University: Palmerston North, New Zealand, 2019.

$562 \quad 7 . \quad$ Bjørn, A.; Richardson, K.; Hauschild, M. Z. A Framework for Development and Communication of 563 Absolute Environmental Sustainability Assessment Methods. J. Ind. Ecol. 2018, 23, (4), 838-854.

$564 \quad$ 8. Ryberg, M. W.; Owsianiak, M.; Richardson, K.; Hauschild, M. Z. Development of a life-cycle impact 565 assessment methodology linked to the Planetary Boundaries framework. Ecol.Indic. 2018, 88, $250-262$.

566 9. Algunaibet, I. M.; Pozo, C.; Galán-Martín, Á.; Huijbregts, M. A. J.; Mac Dowell, N.; Guillén-Gosálbez, G. 567 Powering sustainable development within planetary boundaries. Energy Environ. Sci. 2019, 12, $1890-1900$. 

for effective Earth system governance: Defining key environmental indicators using an enhanced-DPSIR framework. Ecol.Indic. 2018, 90, 577-583.

11. Chandrakumar, C.; McLaren, S. J. Exploring the Linkages Between the Environmental Sustainable Development Goals and Planetary Boundaries Using the DPSIR Impact Pathway Framework. In Designing Sustainable Technologies, Products and Policies: From Science to Innovation, Benetto, E.; Gericke, K.; Guiton, M., Eds. Springer Cham, Switzerland, 2018; pp 413-423.

$575 \quad 12 . \quad$ Afionis, S.; Sakai, M.; Scott, K.; Barrett, J.; Gouldson, A. Consumption-based carbon accounting: does it 576 have a future? Wiley Interdiscip. Rev. Clim. Change 2017, 8, (1), e438.

577 13. Hertwich, E. G.; Peters, G. P. Carbon Footprint of Nations: A Global, Trade-Linked Analysis. Environ. Sci. 578 Technol. 2009, 43, (16), 6414-6420.

579 14. Andrew, R.; Forgie, V. A three-perspective view of greenhouse gas emission responsibilities in New 580 Zealand. Ecol. Econ. 2008, 68, (1), 194-204.

$581 \quad 15 . \quad$ Malik, A.; Lan, J.; Lenzen, M. Trends in Global Greenhouse Gas Emissions from 1990 to 2010. Environ. 582 Sci. Technol. 2016, 50, (9), 4722-4730.

$583 \quad 16 . \quad$ Barrett, J.; Peters, G.; Wiedmann, T.; Scott, K.; Lenzen, M.; Roelich, K.; Le Quéré, C. Consumption-based 584 GHG emission accounting: a UK case study. Clim. Policy 2013, 13, (4), 451-470.

585 17. Chandrakumar, C.; McLaren , S. J.; Malik, A.; Ramilan, T.; Lenzen, M. Understanding New Zealand's 586 consumption-based greenhouse gas emissions: an application of multi-regional input-output analysis. Int. J. Life 587 Cycle Assess. 2019.

18. Steininger, K. W.; Munoz, P.; Karstensen, J.; Peters, G. P.; Strohmaier, R.; Velázquez, E. Austria's consumption-based greenhouse gas emissions: Identifying sectoral sources and destinations. Global Environ. Change 2018, 48, 226-242.

591 19. ISO ISO14067: Carbon Footprint of Products-Parts 1-2; International Organization for Standardization: 592 Geneva, Switzerland, 2013.

$59320 . \quad$ Davis, S. J.; Caldeira, K. Consumption-based accounting of $\mathrm{CO}_{2}$ emissions. Proc. Natl. Acad. Sci. 2010, 594 107, (12), 5687-5692.

595 21. Tukker, A.; Poliakov, E.; Heijungs, R.; Hawkins, T.; Neuwahl, F.; Rueda-Cantuche, J. M.; Giljum, S.; Moll, 596 S.; Oosterhaven, J.; Bouwmeester, M. Towards a global multi-regional environmentally extended input-output 597 database. Ecol. Econ. 2009, 68, (7), 1928-1937.

$598 \quad 22 . \quad$ Cherubini, F.; Fuglestvedt, J.; Gasser, T.; Reisinger, A.; Cavalett, O.; Huijbregts, M. A. J.; Johansson, D. J. 599 A.; Jørgensen, S. V.; Raugei, M.; Schivley, G.; Strømman, A. H.; Tanaka, K.; Levasseur, A. Bridging the gap between 600 impact assessment methods and climate science. Environ. Sci. Policy 2016, 64, 129-140.

601 23. Levasseur, A.; Cavalett, O.; Fuglestvedt, J. S.; Gasser, T.; Johansson, D. J. A.; Jørgensen, S. V.; Raugei, M.; 602 Reisinger, A.; Schivley, G.; Strømman, A.; Tanaka, K.; Cherubini, F. Enhancing life cycle impact assessment from 603 climate science: Review of recent findings and recommendations for application to LCA. Ecol.Indic. 2016, 71, 604 163-174.

605 24. Reisinger, A.; Ledgard, S. F.; Falconer, S. J. Sensitivity of the carbon footprint of New Zealand milk to 606 greenhouse gas metrics. Ecol.Indic. 2017, 81, 74-82.

$60725 . \quad$ IPCC Climate Change 2013 - The Physical Science Basis: Working Group I Contribution to the Fifth 608 Assessment Report of the Intergovernmental Panel on Climate Change; 9781107057999; Cambridge University 609 Press: Cambridge, UK and New York, USA, 2014. 
610 26. Owsianiak, M.; Brooks, J.; Renz, M.; Laurent, A. Evaluating climate change mitigation potential of 611 hydrochars: compounding insights from three different indicators. GCB Bioenergy 2018, 10, (4), $230-245$.

612 27. Reisinger, A.; Havlik, P.; Riahi, K.; van Vliet, O.; Obersteiner, M.; Herrero, M. Implications of alternative 613 metrics for global mitigation costs and greenhouse gas emissions from agriculture. Clim. Change 2013, 117, (4), 614 677-690.

$61528 . \quad$ IPCC Summary for Policymakers. In: Global warming of $1.5^{\circ} \mathrm{C}$. An IPCC Special Report on the impacts of 616 global warming of $1.5^{\circ} \mathrm{C}$ above pre-industrial levels and related global greenhouse gas emission pathways, in the 617 context of strengthening the global response to the threat of climate change, sustainable development, and 618 efforts to eradicate poverty; World Meteorological Organization: Geneva, Switzerland, 2018; p 32.

619 29. Steffen, W.; Richardson, K.; Rockstrom, J.; Cornell, S. E.; Fetzer, I.; Bennett, E. M.; Biggs, R.; Carpenter, 620 S. R.; de Vries, W.; de Wit, C. A.; Folke, C.; Gerten, D.; Heinke, J.; Mace, G. M.; Persson, L. M.; Ramanathan, V.; 621 Reyers, B.; Sorlin, S. Sustainability. Planetary boundaries: guiding human development on a changing planet. 622 Science 2015, 347, (6223), 1259855.

623 30. UNFCCC The Paris Agreement. United Nations Framework Convention on Climate Change: Paris, France, 624 2015. https://unfccc.int/process-and-meetings/the-paris-agreement/the-paris-agreement (accessed 30 Nov, 625 2018)

31. Rogelj, J.; Popp, A.; Calvin, K. V.; Luderer, G.; Emmerling, J.; Gernaat, D.; Fujimori, S.; Strefler, J.; Hasegawa, T.; Marangoni, G.; Krey, V.; Kriegler, E.; Riahi, K.; van Vuuren, D. P.; Doelman, J.; Drouet, L.; Edmonds, J.; Fricko, O.; Harmsen, M.; Havlík, P.; Humpenöder, F.; Stehfest, E.; Tavoni, M. Scenarios towards limiting global mean temperature increase below $1.5^{\circ} \mathrm{C}$. Nat. Clim. Change 2018, 8, (4), 325-332.

$630 \quad 32 . \quad$ Doka, G. Combining life cycle inventory results with planetary boundaries: the planetary boundary allowance impact assessment method PBA'06; Doka Life Cycle Assessment: Zurich, Switzerland, 2016.

632 33. Bjørn, A.; Hauschild, M. Z. Introducing carrying capacity-based normalisation in LCA: framework and 633 development of references at midpoint level. Int. J. Life Cycle Assess. 2015, 20, (7), 1005-1018.

34. Millar, R. J.; Fuglestvedt, J. S.; Friedlingstein, P.; Rogelj, J.; Grubb, M. J.; Matthews, H. D.; Skeie, R. B.; Forster, P. M.; Frame, D. J.; Allen, M. R. Emission budgets and pathways consistent with limiting warming to $1.5^{\circ}$ C. Nat. Geosci. 2017, 10, 741.

$637 \quad 35 . \quad$ Butz, C.; Liechti, J.; Bodin, J.; Cornell, S. E. Towards defining an environmental investment universe 638 within planetary boundaries. Sustain. Sci. 2018, 13, (4), 1031-1044.

36. van den Berg, N. J.; van Soest, H. L.; Hof, A. F.; den Elzen, M. G. J.; van Vuuren, D. P.; Chen, W.; Drouet, 640 L.; Emmerling, J.; Fujimori, S.; Höhne, N.; Kõberle, A. C.; McCollum, D.; Schaeffer, R.; Shekhar, S.; Vishwanathan, 641 S. S.; Vrontisi, Z.; Blok, K. Implications of various effort-sharing approaches for national carbon budgets and 642 emission pathways. Clim. Change 2019.

643 37. Raupach, M. R.; Davis, S. J.; Peters, G. P.; Andrew, R. M.; Canadell, J. G.; Ciais, P.; Friedlingstein, P.; Jotzo, 644 F.; van Vuuren, D. P.; Le Quéré, C. Sharing a quota on cumulative carbon emissions. Nat. Clim. Change 2014, 4, 645873.

$646 \quad 38 . \quad$ Ryberg, M. W.; Owsianiak, M.; Clavreul, J.; Mueller, C.; Sim, S.; King, H.; Hauschild, M. Z. How to bring 647 absolute sustainability into decision-making: An industry case study using a Planetary Boundary-based 648 methodology. Sci. Total Environ. 2018, 634, 1406-1416.

649 39. Häyhä, T.; Lucas, P. L.; van Vuuren, D. P.; Cornell, S. E.; Hoff, H. From Planetary Boundaries to national 650 fair shares of the global safe operating space - How can the scales be bridged? Global Environ. Change 2016, $65140,60-72$. 
40. Chandrakumar, C.; McLaren, S. J.; Jayamaha, N. P.; Ramilan, T. Absolute Sustainability-Based Life Cycle Assessment (ASLCA): A Benchmarking Approach to Operate Agri-food Systems within the $2^{\circ} \mathrm{C}$ Global Carbon Budget. J. Ind. Ecol. 2019, 23, (4), 906-917.

41. Sandin, G.; Peters, G. M.; Svanström, M. Using the planetary boundaries framework for setting impactreduction targets in LCA contexts. Int. J. Life Cycle Assess. 2015, 20, (12), 1684-1700.

42. Andersen, C. E.; Ohms, P.; Rasmussen, F. N.; Birgisdottir, H.; Birkved, M.; Hauschild, M.; Ryberg, M. Assessment of absolute environmental sustainability in the built environment. Build. Environ. 2020, 106633.

43. Lucas, P.; Wilting, H. C. Using planetary boundaries to support national implementation of environmentrelated Sustainable Development Goals; PBL Netherlands Environmental Assessment Agency: The Hague, The Netherlands, 25 Sep, 2018; p 54.

44. Chandrakumar, C.; Malik, A.; McLaren, S. J.; Lenzen, M.; Ramilan, T.; Jayamaha, N. P. New Zealand AgriFood Sector and Absolute Climate Impacts: An Application of Multi-Regional Input-Output Analysis. In Eleventh Int. Conf. Life Cycle Assessment of Food 2018 Bangkok, Thailand, 2018.

45. Dao, H.; Peduzzi, P.; Friot, D. National environmental limits and footprints based on the Planetary Boundaries framework: The case of Switzerland. Global Environ. Change 2018, 52, 49-57.

46. Reisinger, A.; Ledgard, S. Impact of greenhouse gas metrics on the quantification of agricultural emissions and farm-scale mitigation strategies: A New Zealand case study. Environ. Res. Lett. 2013, 8, (2).

47. MfE Climate Change Response (Zero Carbon) Amendment Bill: Summary; Ministry for the Environment: Wellington, New Zealand, 2019; p 17.

48. Upton, S. A Zero Carbon Act for New Zealand: Revisiting Stepping stones to Paris and beyond; Parliamentary Commissioner for the Environment: Wellington, New Zealand, 2018; p 47.

49. Lenzen, M.; Moran, D.; Kanemoto, K.; Geschke, A. Building Eora: A Global Multi-Region Input-Output Database at High Country and Sector Resolution. Econ. Syst. Res. 2013, 25, (1), 20-49.

50. Lenzen, M.; Kanemoto, K.; Moran, D.; Geschke, A. Mapping the Structure of the World Economy. Environ. Sci. Technol. 2012, 46, (15), 8374-8381.

51. Lan, J.; Malik, A.; Lenzen, M.; McBain, D.; Kanemoto, K. A structural decomposition analysis of global energy footprints. Appl. Energy 2016, 163, 436-451.

52. Malik, A.; Lan, J. The role of outsourcing in driving global carbon emissions. Econ. Syst. Res. 2016, 28, (2), 168-182.

53. Gidden, M. J.; Riahi, K.; Smith, S. J.; Fujimori, S.; Luderer, G.; Kriegler, E.; van Vuuren, D. P.; van den Berg, M.; Feng, L.; Klein, D.; Calvin, K.; Doelman, J. C.; Frank, S.; Fricko, O.; Harmsen, M.; Hasegawa, T.; Havlik, P.; Hilaire, J.; Hoesly, R.; Horing, J.; Popp, A.; Stehfest, E.; Takahashi, K. Global emissions pathways under different socioeconomic scenarios for use in CMIP6: a dataset of harmonized emissions trajectories through the end of the century. Geosci. Model Dev. 2019, 12, (4), 1443-1475.

54. Bjørn, A.; Margni, M.; Roy, P.-O.; Bulle, C.; Hauschild, M. Z. A proposal to measure absolute environmental sustainability in life cycle assessment. Ecol.Indic. 2016, 63, 1-13.

55. Brejnrod, K. N.; Kalbar, P.; Petersen, S.; Birkved, M. The absolute environmental performance of buildings. Build. Environ. 2017, 119, 87-98.

56. Chandrakumar, C.; McLaren, S.; Dowdell, D.; Jaques, R. A top-down approach for setting climate targets for buildings: the case of a New Zealand detached house. In Sustainable Built Environment Conference, IOP Publishing: Graz, Austria, 2019; Vol. 323, p 012183. 
58. UNEP Global Guidance for Life Cycle Impact Assessment Indicators: Volume 1; United Nations Environment Programme: Paris, France, 2016; p 166.

59. Krabbe, O.; Linthorst, G.; Blok, K.; Crijns-Graus, W.; van Vuuren, D. P.; Hohne, N.; Faria, P.; Aden, N.; Pineda, A. C. Aligning corporate greenhouse-gas emissions targets with climate goals. Nat. Clim. Change 2015, 5, (12), 1057-1060.

60. CDP; WRI; WWF Sectoral Decarbonization Approach: A method for setting corporate emission reduction targets in line with climate science. CDP, WRI and WWF: London, UK, 2015. https://sciencebasedtargets.org/sda/ (accessed 12 May, 2019)

61. Girod, B.; van Vuuren, D. P.; Hertwich, E. G. Climate policy through changing consumption choices: Options and obstacles for reducing greenhouse gas emissions. Global Environ. Change 2014, 25, 5-15.

62. Bjørn, A.; Kalbar, P.; Nygaard, S. E.; Kabins, S.; Jensen, C. L.; Birkved, M.; Schmidt, J.; Hauschild, M. Z. Pursuing necessary reductions in embedded GHG emissions of developed nations: Will efficiency improvements and changes in consumption get us there? Global Environ. Change 2018, 52, 314-324.

63. Leining, C.; Kerr, S. A Guide to the New Zealand Emissions Trading Scheme; Motu Economic and Public 709 Policy Research: Wellington, New Zealand, 2018; $\mathrm{p} 15$.

64. ICAP New Zealand Emissions Trading Scheme; International Carbon Action Partnership: Berlin, Germany, 2019; p 6.

65. Girod, B.; Van Vuuren, D. P.; Hertwich, E. G. Global climate targets and future consumption level: an evaluation of the required GHG intensity. Environ. Res. Lett. 2013, 8, (1), 014016. input-output analysis. Part 2: Simulation. Ecol. Econ. 2013, 86, 188-198. Rueda-Cantuche, J. M. Environmental impacts of changes to healthier diets in Europe. Ecol. Econ. 2011, 70, (10), $718 \quad 1776-1788$. approach. Energy Policy 2016, 94, 114-125.

69. Font Vivanco, D.; van der Voet, E. The rebound effect through industrial ecology's eyes: a review of LCAbased studies. Int. J. Life Cycle Assess. 2014, 19, (12), 1933-1947. the misrepresentations of CO2-equivalent emissions of short-lived climate pollutants under ambitious mitigation. NPJ Clim. Atmos. Sci. 2018, 1, (1), 16. understanding the impacts of any scale of human activity in the context of the Planetary Boundaries. Sustain. Earth 2018, 1, (1), 4. Arora, V. K.; Beerling, D. J.; Bergamaschi, P.; Blake, D. R.; Brailsford, G.; Brovkin, V.; Bruhwiler, L.; Crevoisier, C.; Crill, P.; Covey, K.; Curry, C.; Frankenberg, C.; Gedney, N.; Höglund-Isaksson, L.; Ishizawa, M.; Ito, A.; Joos, F.; Kim, H. S.; Kleinen, T.; Krummel, P.; Lamarque, J. F.; Langenfelds, R.; Locatelli, R.; Machida, T.; Maksyutov, S.; 
Peng, C.; Peng, S.; Peters, G. P.; Pison, I.; Prigent, C.; Prinn, R.; Ramonet, M.; Riley, W. J.; Saito, M.; Santini, M.; Schroeder, R.; Simpson, I. J.; Spahni, R.; Steele, P.; Takizawa, A.; Thornton, B. F.; Tian, H.; Tohjima, Y.; Viovy, N.; Voulgarakis, A.; van Weele, M.; van der Werf, G. R.; Weiss, R.; Wiedinmyer, C.; Wilton, D. J.; Wiltshire, A.; Worthy, D.; Wunch, D.; Xu, X.; Yoshida, Y.; Zhang, B.; Zhang, Z.; Zhu, Q. The global methane budget 2000-2012. Earth Syst. Sci. Data 2016, 8, (2), 697-751.

740 73. Rogelj, J.; Luderer, G.; Pietzcker, R. C.; Kriegler, E.; Schaeffer, M.; Krey, V.; Riahi, K. Energy system 741 transformations for limiting end-of-century warming to below $1.5^{\circ} \mathrm{C}$. Nat. Clim. Change 2015, 5, 519.

742 74. Chandrakumar, C.; McLaren, S. J.; Dowdell, D.; Jaques, R. A science-based approach to setting climate 743 targets for buildings: The case of a New Zealand detached house. Build. Environ. 2020, 169, 106560. 